\title{
Intersections
}

Canadian Journal of Music

Revue canadienne de musique

\section{To All Who Should Be Concerned}

\section{Dylan Robinson}

Volume 39, numéro 1, 2019

Decolonizing Music Pedagogies

URI : https://id.erudit.org/iderudit/1075347ar

DOI : https://doi.org/10.7202/1075347ar

Aller au sommaire du numéro

\section{Éditeur(s)}

Canadian University Music Society / Société de musique des universités canadiennes

\section{ISSN}

1918-512X (numérique)

Découvrir la revue

\section{Citer ce document}

Robinson, D. (2019). To All Who Should Be Concerned. Intersections, 39(1), 137-144. https://doi.org/10.7202/1075347ar

\section{Résumé de l'article}

xexé:yltholetsel te sqwà:ls te'ile tl'ekwelep tél:exwatlha ye s'í:wes shxwélméxwelh. xéyxewetholetsel. ólew híth kw'elsu ó:lmethome. eyeléwthelh. tl'élexw kw'a's qel í:weselep. éy kw's totí:ltset, lheqtó:léstexwtset te syó:ys te í. ewe qelélweselep. xwelítem skwukwelstéleq talhwélep, maytólxwchapcha (xwélmexw, lets'ô:lmexw) tlowáyél, qas te wáy:eles.

Cette lettre décrit certains fondements et changements de base structurels qui doivent être implantés dans les cursus musicaux de façon à parvenir à des formes décoloniales d'éducation musicale. Cette lettre sert de point de départ pour de tels changements, lesquels devraient toujours être dirigés par des Autochtones, des Noirs, des Latinos, des Asiatiques et d'autres universitaires et artistes de couleurs (PANDC) qui vivent et travaillent sur les lieux où les programmes de musique sont basés. Le changement initié par les communautés est impératif pour éviter de reproduire des systèmes normatifs d'éducation musicale qui ne font qu'inclure divers contenus. Cette lettre soutient que les transformations émergeant des modifications au curriculum et de l'embauche d'universitaires PANDC peuvent être comprises comme une forme d'inclusion additive. Les modèles d'inclusion additive procèdent en normalisant divers contenus, tandis que les structures suprématistes blanches de la pédagogie demeurent inchangées. Par conséquent, l'inclusion additive maintient au pouvoir ceux qui choisissent le contenu à inclure, au lieu de faire place au leadership des PANDC pour déterminer les paramètres du changement ainsi que les manières dont les structures fondamentales de l'éducation musicale devraient être démantelées et renouvelées.
(C) Canadian University Music Society / Société de musique des universités canadiennes, 2021
Ce document est protégé par la loi sur le droit d'auteur. L’utilisation des services d'Érudit (y compris la reproduction) est assujettie à sa politique d'utilisation que vous pouvez consulter en ligne.

https://apropos.erudit.org/fr/usagers/politique-dutilisation/ 


\section{TO ALL WHO SHOULD BE CONCERNED}

ey swayel heads of music departments, directors and deans of music schools, and all those including faculty and staff who work in music programs, departments and schools,

ey swayel 1 sí:yáye sí:yám, all those who hold the power to enact change,

I address this letter to you directly, and as succinctly as possible because of the urgency we are faced with to transform the unmarked, white supremacist, and settler colonial structures that guide our music education systems. ${ }^{1}$ As the continuation of anti-Black and anti-Indigenous violence of the past months, years, and lifetimes has made evident, the time has ended for further working groups and "Equity, Diversity and Inclusion" (EDI) recommendation committees on how we as educators across all scholarly disciplines must work toward systemic forms of change that are decolonial and anti-racist. ${ }^{2}$ We no longer have the luxury of proceeding with small steps, and snail's-pace increments. My colleagues in music, you should know by now what needs to be done in order to truly transform systems of music education into spaces where different epistemologies and values of music and world views are equally supported. Given the limited transformation I have seen in music programs despite years of reports, recommendations, and activism, it is clear to me and many others that you do not.

This letter is one attempt, among many previous attempts by Indigenous, Black, Latinx, Asian, and other scholars and artists of colour (IBPOC), to be clear about the substantive change music programs need to make. ${ }^{3}$ While it is important to note the beginnings of change taking place, the majority of this change has been represented by diversifying curriculum and hiring IBPOC faculty. Both kinds of change are necessary. Without substantive change to the structures that underpin what I characterize as "additive" inclusion, however, these changes can in fact maintain the larger system of white supremacy within which music programs operate. This is particularly the case where such hires represent an increase in IBPOC faculty by a small percentage of the overall faculty makeup, and where curricular change involves adding a week focused on Indigenous, Black, Latinx, or other cultural content, or to include a new course or two, for example. I have come to understand the focus on diversifying curriculum to foreclose upon or forestall the structural change that is needed at this juncture. Gestures of inclusion maintain the power of those 
who choose to include, rather than giving over space for IBPOC leadership to determine the parameters for change. Again, to be clear: decolonizing music programs involves challenging the received values of such programs, and from this, substantial restructuring of such programs' core systems. To this end, this brief letter will list some of these structures foundationally embedded in music programs that entrench the centrality of Western music. I address you directly as a way to "call in" music faculty and administrators to undertake this essential work of structural change. I am addressing you as colleagues, as friends, and as leaders with significant power to effect this change.

xwélmexw (Stó:lō people) open our gatherings by addressing those present with the phrase in Halq’eméylem "el siyam siya:ye," which translates as "my good friends," but also "respected leaders." We open this way not just to promote good feelings among those gathered, but to recognize that those who gather have accountability to their positions and roles as leaders who are able to bring about the work that needs to be done.

el siyam siya:ye, there is work that urgently needs to be done.

el siyam siya:ye, there is work that you need to do.

\section{Instructions for Structural Change}

The following list should not be taken as an exhaustive checklist of substantive change that needs to be undertaken by music programs, but merely a beginning to this work. This list is not offered as a singular solution, but the beginnings of a much larger process that must be defined by faculty and students within specific programs, and in relation with the IBPOC communities who reside in proximity to the university, and Indigenous peoples whose lands the university occupies.

1. Abolish the current configuration of entrance requirements, including the "entrance audition," as white supremacist forms of gatekeeping that centralize Western music performance and Western "rudiments of music" (including learning scales, and intervals in Western musical traditions only), and are prejudiced against other musical knowledge and value systems. For those students who are allowed into music programs without passing such auditions (or components of them), "remedial" coursework is required that provides the missing "rudiments" of musical knowledge. These entrance requirements above all other structures perpetuate and solidify the hegemony of Euro-American repertoire, music history, and analysis, and exclude music students who have deep knowledge of and skill in non-Western musical practices.

2. Re-evaluate what kinds of students your program seeks to support and benefit. I have often heard faculty refuse calls to re-balance the emphasis upon Western musical values and Euro-American repertoire by saying, "But this is what our students want," or "But this 
is what our students are here to learn." One answer to this supposed challenge is to rebalance our music student demographics to equally represent students engaged in all kinds of music making, creation, and thinking, and to support their development across these areas in our programs. Define student recruitment strategies that prioritize drawing IBPOC students into your programs, ensure students from marginalized economic backgrounds have the financial support and mentorship to succeed, and allow them opportunities to develop some degree of autonomy or self-determined path through the program. That is, rather than shaping IBPOC to fit the program's goals, allow them to reshape the program and the forms of community in place.

3. End the dominance of Western art music performance, historical knowledge, "rudiments" of music (and centralized Western forms of popular music to a lesser extent) across your curriculum. Do not do so by merely "adding diversity." Do not do so by merely peppering your courses with IBPOC perspectives and readings. Change the entire makeup of your courses, their outcomes, their progression, and their fixation upon "coverage" that extends primarily to Western historical knowledge. ${ }^{4}$ Devote part of all courses to an intersectional analysis of how structures of white supremacy, settler colonialism, and heteropatriarchy have underpinned music education, composition, music analysis, and music history. Gather resources on intersectional critical race historiographies of music education, musicology, composition, performance, and music analysis to share with students and faculty. Work with your teaching and learning centres on strategies for imbricating this critical race historiography of musicology, performance, music education, analysis, and composition into courses.

4. End the dominance of Western hetero-patriarchal musical performance and knowledge represented by your sessional, continuing adjunct, tenure-track, and tenured faculty. End the dominance of white male leadership. Make a long-term strategic hiring plan that results in at least 50 per cent of your faculty representation by IBPOC scholars, composers, and musicians who work within community-centred, politicized, and activist areas of research and artistic practice. This does not necessarily mean eradicating a tenure line in a particular historical area, but perhaps instead finding an IBPOC scholar who examines that same area within a context of Indigenous, Black, and other POC history. This will also mean investing in tenured/tenure-track faculty who teach different forms of popular music, songwriting and production, and musicians who represent local and Indigenous musical practices.

5. Affirm that there are many epistemologies of music, and that they are not mutually exclusive. Understand that many cultures consider song to have life, and have more-than-aesthetic functions, and 
consequently, by applying Western structures of analysis, composition, and presentation to this music you risk enacting epistemic violence toward this music. 5

6. End the dominance of pedagogy that dictates the core skills that serve as a foundation for unmarked "musical excellence." Extend the focus of "ear training" to consider multiple forms of listening, including a critical awareness of how one's layered, non-static positionality guides our listening values and priorities. Move beyond the essay and exam as the primary forms for assessing what has been learned. Offer other creative forms of communicating ideas beyond essay writing. Prioritize your own and your students' opportunities to learn these forms. The essay is only one of many structures for conveying knowledge and ideas, and has its own epistemic violence. Acknowledge that analysis also comes in many forms and is not exclusive to Western models. Educate yourself on other non-Western forms of analysis, including non-Western forms of structural analysis, and alternative holistic forms of analysis, including analyzing our sensory-affective reception of music. Acknowledge that certain forms of analysis and writing may propagate a model of knowledge-as-resource extraction, or a flattening, atomizing, and even the violent dismemberment of the life that other cultures consider their music and song to have. Support methods of analysis and modes of representation that refuse extractive logics.

7. Assess the ways in which your program is connected with and disconnected from the IBPOC communities in your area. Ask yourself, "Do we centre these folx and the knowledge they hold through invitations for them to teach, perform in, or permanently join our program as faculty? Do we provide opportunity for Indigenous people to share histories of the lands on which our program is situated? Have we provided space for Indigneous people of the lands we occupy to share music and sonic knowledge, but allow that knowledge to be shared in the ways they deem necessary? Do we honour what they share through Indigenous knowledge-sharing protocols-do we understand what those are?" If not, these things must also change. Invite members of IBPOC communities (and in doing so, pay them for their time and expertise, following their protocol) to provide their expert guidance not just for your students, but toward rebuilding your music program. Implement their recommendations. Use your resources to manifest their vision.

8. At your next strategic visioning exercise, at your next department retreat, and at your next department meeting, interrogate these and other foundational structures and values of your program(s). Unpack the normativity of those foundations that you hold close, and the practices and knowledge that you love. Learn to let some of them go, while adapting others. Acknowledge what has been done to address the calls for change listed here and what change 
has not yet taken place. Together with IBPOC faculty, students, and community members, make lists of your own that articulate other specific structures of white supremacy and settler colonialism that underpin your program, and why they are problems.

9. Account publicly for the change based on the above actions (and beyond), as well as the lack thereof-at conferences, on your website, to your students, to your colleagues, to your families. Share openly with colleagues what changes have been implemented and how. Account for the change you enact, and your failure to enact change here, in Intersections.

I'd like to close by emphasizing the need to help amplify IBPOC voices that have called (again) for the necessity of demonstrating more than performative allyship. Frequently, this work stalls because of the current state of music programs where there are few IBPOC scholars present in music programs-often pre-tenure or adjunct members of faculty-who are expected to lead this work against a sea of resistance. One way to address this is through an allyship of persistent, embodied obstruction to the normative processes you participate in within the music programs you are a part of. This embodied obstruction may take many forms of alliance around the table: calling out racism, through affective labour, by standing up in support, and through insistence. It comes especially through continued conversation about the necessity of this change with colleagues who resist letting go of the tight embrace of what is loved, and letting go of belief in a singular set of standards that are understood as "excellence" but that conflate such supposed excellence with Western musical standards. In some of these cases, this may require your labour to act, when necessary, as a "\#settlercollector." This hashtag has its origins as a call by Indigenous people online to request help from settlers to educate other settlers about decolonization and white supremacy, and also point them toward writing and media resources by Indigenous people on Indigenous history, politics, and culture. What I suggest here is that the role of \#settlercollector also has a place in music department meetings, colloquia, and other gatherings in order to lessen the burden on IBPOC folx to provide basic education outside of the classroom in anti-racism and decolonization. ${ }^{6}$ Such allied labour enables IBPOC folx to redirect our energies toward the urgent work of resurgence with and for our communities.

Most First Nations communities on the Northwest Coast have practices of accountability that are materialized variously as "shaming poles," "ridicule masks," or performed as "shaming/ridicule songs." At the heart of these practices is the aim of calling community leaders to task for not upholding their responsibilities to support the health and well-being of their family or community. These practices developed as a way to call publicly for our leaders (hereditary chiefs and matriarchs, síya:m) to be accountable. The Western concepts of shame and ridicule were applied by anthropologists to traditions they were struggling to grasp. Shaming and ridicule were the closest analogies they could find for this work, even though such concepts held little place in Northwest Coast political epistemologies. I am neither a carver nor a song carrier, but I 
ask you to consider this letter as a written variation of such forms of direct address offered here with the same necessity, urgency, and accountability called for by these traditions. By this letter, published here in Intersections, I am publicly calling you - 1 sí:yáye sí:yám-as members of my community, and leaders within music programs whom I respect deeply, to move significantly beyond models of curricular inclusion. The actions in the above list should be taken as essential but not exhaustive; I hope they serve as a beginning that should be extended through the leadership of other IBPOC faculty and leaders in your individual programs, and by prioritizing deep engagement with the different needs of local communities.

\section{wel th'it, DyLAN RoBinson}

\section{ENDNOTES}

For their generous feedback on this letter I would like to thank Patrick Nickleson, a postdoctoral researcher at Queen's University, and Ellen Waterman, Helmut Kallmann Chair for Music in Canada at Carleton University. In addition to being published in Intersections, this letter will be sent to deans and heads of music departments and schools in Canada, alongside specific faculty allies in these departments and schools whom I will ask to serve as witnesses to the ongoing change called for here, and to publicly account for such change and any lack thereof.

1 Do not conflate the use of "white supremacist" here with slander or dismissal. Do not conflate it with being called racist or "bad." The legal scholar Cheryl I. Harris has written of white supremacy as a form of property, with great care taken by courts, police, and institutions to uphold "the exclusion of others deemed to be 'not white." Whiteness has long been premised not on difference, Harris writes, but supremacy: "White' was defined and constructed in ways that increased its value by reinforcing its exclusivity." See "Whiteness as Property," Harvard Law Review 106, no. 8 (1993): 1737. For an updated take on Harris's ideas from an Australian Indigenous perspective, see Aileen Moreton-Robinson, The White Possessive: Property, Power, and Indigenous Sovereignty (Minneapolis: University of Minnesota Press, 2015).

2 The term "EDI" postdates the most extended, critical take on institutional racism and diversity work. In On Being Included: Racism and Diversity in Institutional Life, Sara Ahmed writes,

Solutions to problems can create new problems. There is more to say about the consequences of institutional racism becoming an "institutional admission." I am uneasy about what it means for a subject or institution to admit to racism. If racism is shaped by actions that are not seen by those who are its beneficiaries, what does it means for those beneficiaries to see it? We could suppose that the definition restricts racism to what we can see: it claims that racism "can be seen or detected" in certain forms of behavior. I suggest the declaration might work by claiming to see racism (in what the institution fails to do) and by maintaining the definition of racism as unseeing. If racism is defined as unwitting and collective prejudice, then the claim to be racist by being able to see racism in this or that form of practice is also a claim not to be racist in the same way.... [S]aying "We are racist" becomes a claim to have overcome the conditions (unseen racism) that require the speech act in the first place. (Durham, NC: Duke University Press, 2012), 46

For a critique of the dangers of new problems that arise from old problems in the context of Canadian multicultural inclusion, see Eva Mackey, The House of Difference: Cultural Politics and National Identity in Canada (Toronto: University of Toronto Press, 2002); and Dylan Robinson, Hungry Listening: Resonant Sense for Indigenous Sound Studies (Minneapolis: University of Minnesota Press, 2020).

3 Most recently, this includes Phillp Ewell's 2019 plenary presentation at the Society for Music Theory annual conference, "Music Theory's White Racial Frame" and his subsequent six-part blog, "Confronting Racism and Sexism in American Music Theory" (2020). It also includes Danielle Brown's "An Open Letter on Racism in Music Studies: Especially Ethnomusicology and Music Education" (12 June 2020) on her blog My People Tell Stories, as well as much work undertaken by the Project Spec- 
trum consortium of scholars across music theory, musicology, and ethnomusicology. This is far from a complete list of the work that addresses white supremacy in music departments, programs, and scholarly societies.

4 Elsewhere, I have made the argument that we need to begin by considering curriculum as a "ground" or "foundation," that is, as an educational equivalent to the lands occupied by settlers, that like our lands needs also to be given back:

What happens when we formally acknowledge in a department meeting the lack of decolonized core curricula? I name "core curricula"- the core history, the theory, the artistic practices-in particular, since it serves as a "ground" for the discussions we want to build on with our students. If we think of our curricula as "the ground," we might then also consider core curricula as the educational equivalent of land. It might then follow that in order for decolonization not to merely be a metaphor ..., curriculum might need to be one of the things "given back," where curriculum is the ground that we provide through the courses, the texts, and the performances we teach. Substantive forms of redress that Indigenous people call for are not reducible to the singularity of "the land," but include other foundations, other ground. What foundations are you (perhaps inadvertently) reinforcing? What ground are you occupying, and inviting others-your students, your colleagues-to occupy? Foundations are equally reinforced by refusals to refuse. You might, to yourself and others, acknowledge that you need to give over these foundations, this ground. Perhaps you need to give them over entirely, and then work to rebuild. To give these over, entirely, does not mean you will no longer teach what you love to teach or what has value-Brecht, Shakespeare, Stravinsky, the Beatles-but instead that you might practise forms of "settler refusal" for the perpetuation of settler colonial structures that demand a "fitting in" of non-Western, Indigenous, and BPOC work into pre-existing era-based progressions, into the canon. (Dylan Robinson, "Rethinking the Practice and Performance of Indigenous Land Acknowledgement," Canadian Theatre Review 177 [Winter 2019]: 20-1)

5 The concept of "epistemic violence" was developed by Gayatri Spivak and has since become a central term in anti-racist and decolonizing scholarship. In Decolonizing Methodologies: Research and Indigenous Peoples, Linda Tuhiwai Smith writes that state violence has been committed for centuries, not just against Indigenous bodies, but against Indigenous knowledge systems and ways of knowing: "Differences between Western and indigenous conceptions of the world have always provided stark contrasts. Indigenous beliefs were considered shocking, abhorrent and barbaric and were prime targets for the efforts of missionaries. Many of those beliefs still persist; they are embedded in indigenous languages and stories and etched in memories" (London: Zed Books, 1999, 43).

6 The hashtag \#settlercollector began appearing on Twitter in early 2018, particularly in the wake of the acquittal of Gerald Stanley for the murder of Colten Boushie. Indigenous folx use the hashtag to call in settler allies to "collect" settlers who demonstrate ignorance, take up space, and antagonize IBPOC online and on social media. That is, the hashtag is directed to settler allies to help by taking on the labour of (re)explaining to settlers why their words, actions, or commentary are racist, colonizing, offensive, dangerous, or otherwise in danger of inflicting trauma on Indigenous people. 
xexééyltholetsel te sqwà:ls te'íle tl'ekwelep tél:exwatlha ye s'í:wes shxwélméxwelh. xéyxewetholetsel. ólew híth kw'elsu ó:lmethome. eyeléwthelh. tl'élexw kw’a's qel í:weselep. éy kw’s totí:ltset, lheqtó:léstexwtset te syó:ys te í. ewe qelélweselep. xwelítem skwukwelstéleq talhwélep, maytólxwchapcha (xwélmexw, lets'ô:lmexw) tlowáyél, qas te wáy:eles.

\begin{abstract}
ABSRACT
This letter describes some of the foundation and basic structural changes that must be implemented by music programs in order to move toward decolonial forms of music education. The letter serves as one starting point for such change among many that must always be led by Indigenous, Black, Latinx, Asian and other scholars / artists of colour (IBPOC) who live and work in the locations where music programs are based. Community-led change is imperative in order to avoid the replication of normative systems of music education that merely include diverse content. The letter asserts that while curricular change and hiring of IBPOC scholars constitute one part of this change, it might also be understood as a form of additive inclusion. Models of additive inclusion proceed by placing diverse content within normative, white supremacist structures of pedagogy that remain unchanged. Additive inclusion consequently maintains the power of those who choose what content to include, rather than giving over space for IBPOC leadership to determine the parameters for change, and to determine how foundational structures of music education should be dismantled and renewed.
\end{abstract}

\title{
RESUMÉ
}

Cette lettre décrit certains fondements et changements de base structurels qui doivent être implantés dans les cursus musicaux de façon à parvenir à des formes décoloniales d'éducation musicale. Cette lettre sert de point de départ pour de tels changements, lesquels devraient toujours être dirigés par des Autochtones, des Noirs, des Latinos, des Asiatiques et d'autres universitaires et artistes de couleurs (PANDC) qui vivent et travaillent sur les lieux où les programmes de musique sont basés. Le changement initié par les communautés est impératif pour éviter de reproduire des systèmes normatifs d'éducation musicale qui ne font qu'inclure divers contenus. Cette lettre soutient que les transformations émergeant des modifications au curriculum et de l'embauche d'universitaires PANDC peuvent être comprises comme une forme d'inclusion additive. Les modèles d'inclusion additive procèdent en normalisant divers contenus, tandis que les structures suprématistes blanches de la pédagogie demeurent inchangées. Par conséquent, l'inclusion additive maintient au pouvoir ceux qui choisissent le contenu à inclure, au lieu de faire place au leadership des PANDC pour déterminer les paramètres du changement ainsi que les manières dont les structures fondamentales de l'éducation musicale devraient être démantelées et renouvelées. 